This is an open access article under the terms of the CC-BY 3.0 License.

Peer review method: Double-Blind

Date of acceptance: November 16, 2020

Date of publication: January 08, 2021

Original scientific article

DOI: https://www.doi.org/10.47305/JLIA2163024g

\title{
IMMIGRANT PLAYERS IN THE NATIONAL FOOTBALL TEAM OF GERMANY AND THE QUESTION OF NATIONAL IDENTITY
}

\author{
Ahmet Görgen \\ Institute of Political Science, Justus Liebig University of Giessen, Germany \\ ORCID iD: https://orcid.org/0000-0001-9647-2691 \\ ahmetgorgen@hotmail.com
}

\begin{abstract}
This paper is based on the research related to the immigrant players in the national football team and the formation of national identity in Germany. Recent analyses reveal that the success of an immigrant player in the national sports team has been regarded as a useful factor to attract public attention to the contribution of immigrants to the progress of the country. During the matches, discourses coming from the fans depending on the result of the game. They target immigrant players as a scapegoat in the situation of loss. Indeed, this is visible in parallel with the increasing strong critics in the media against these immigrant players. In this paper, the case of Mesut Özil in the German National Football Team is analyzed. The case study offers evidence of whether the success of immigrant players has been an important factor for their inclusion in the national identity in Germany.
\end{abstract}

Keywords: Immigrant Players; Success; Integration; German Identity; Mesut Özil 


\section{INTRODUCTION}

In the literature, the research on the sport and identity formation is found mainly on the function of sports matches. Notable research followed both the function of the sport matches and their connection to society. Thus, how this connection created debates on identity and nationality through new public communication tools are important research focuses. While the research pointed to the minor influence of the media $^{1}$ from the early formation, their analyzes clarified that its effect significantly increased for the identity formation in the historical evolution process. So, in the historical development process, starting from newspapers and magazines, the development of radio and TVs expanded the national sports teams' area of popularity for shaping the national identity. Moreover, in the contemporary world, the development of internet technology and social media provided a better ground for the players of the national teams' to interact with a society that opens new channels for shaping the national identities.

This paper aims to analyze the function of the success of the immigrant players in the national football team of Germany for inclusion in the national identity formation. In this regard, the role of media in the agenda-setting and molding the public opinion and its influence on the widening of the existing hegemonic perspectives on national identity are given an emphasis. As the research topic clarifies, in line with Gramsci's concept of cultural hegemony, ${ }^{2}$ an analysis is conducted on the function of the success of the immigrant players in the national football team of Germany for inclusion in the national identity formation concerning the role of media. In this sense, concerning the media, from newspapers to magazines as well as radio, TV, and social media, analysis is made to present their functions of national identity formation through bringing the national sports games as well as players into the public agenda. In the qualitative methodological base, literature review, research, and analysis of the media discourses are conducted. Thus, a theoretically informed, empirical analysis over the role of the success of immigrant players in the national football team of Germany for inclusion in the national identity formation, concerning the media's contribution, is presented.

First, major debates will be given over the historical development of the relationship between social identity and sport about the function of the media and its widening hegemonic perspectives over the national football games in Germany. Later, the case of Mesut Özil in the German National Football Team is presented as the case of players' interaction with the media, national institutions, and hegemonic identity

\footnotetext{
${ }^{1}$ In this study, the media is referred as a space, including radio, TV, newspaper, magazines, the internet and social media that create connection among the people.

${ }^{2}$ Gramsci's concept of cultural hegemony refers the formation of hegemonic perspective of bourgeoisie based on their values, ideas, worldviews and expectations over the lower classes. In this sense, the media is regarded as a place for the formation of hegemony through directing the society to certain understandings (Heywood 1994, 100).
} 
perspective. Overall, with this study a theoretically informed empirical analysis over the function of the media is given, not only its effect over influencing the national identity in relation with the sports, but directing the public behavior to the desired way over immigrant players of the national football team of Germany.

\section{HISTORICAL EVOLUTION OF THE NATIONAL IDENTITY AND SPORT IN GERMANY}

When the post-WWII is analyzed, during the reconstruction of Europe after a very destructive war, the sports had a positive impact, especially for the national identity formation. The gymnastics and various physical exercises were used as a part of the nationalist and identity constructing perspectives that were regarded as the responsibility of each nation to govern this area for the physical well-being of its citizens (Goksoyr 2010, 268-294). While this has been true for many European countries, because of Germany's Nazi past of dealing nationalism with racist actions, the nationalist dimension of the sport was not taken into account in public arenas but rather it was regarded as a sporting activity of Germany's youth.

Moreover, with the 2000s, following the global trend, sport and the success of the national football team in the international competitions gradually turn into a source of pride for Germany's public. This is also related to Germany's success in the development policy and becoming the EU's major economic power as it made Germany a global player in the world's economic and political matters. The most important indicator, in this case, is the 2006 World Cup that was organized in Germany. Different from the earlier period, the World Cup in 2006 was the scene of German youth's visibility in Germany's matches. This visibility was with waving the flag of Germany, painting their faces with the colors of the German flag, and rediscovering their German identity through the success stories of their national football team (Hyde 2006).

As it was argued, Germany was the major economic power in Europe in the 2000s with the effect of high industrial growth. This had a root of migrations coming from Southern and Eastern Europe, especially from Italy, Greece, and Turkey. Starting from the 1950s, migration from these countries gradually increased that brought young workers for Germany's industrial development (Milewski 2007, 859-896). While these workers were first regarded as 'Gastarbeiter' (guest workers), because of their further presence in the country as well as increasing their public visibility brought a new integration problem for Germany's public sphere.

Furthermore, from education to social life, this integration problem has been a major obstacle for Germany's inability of absorbing these workers in Germany's national identity formation. However, sports provided a new ground for the immigrant workers and their children to have visibility and interaction with the German public with their contribution to the success of the competing teams in both national and international 
arenas. While these immigrant children were having a problem of visibility in education and economic arenas, they discovered the area of sport for having public visibility with their success (Kleindienst-Cachay 2011, 92-108).

As the German football players with Turkish roots of the German national team, this period brought important stars that were actively contributing to Germany's success in football in the international arena. These are Mehmet Scholl played between 1995 and 2002, Mustafa Doğan played from 1999 to 2003, Serdar Taşçı played from 2008 to 2010, Mesut Özil played from 2008 to 2018, İlkay Gündoğan plays from 2012, Emre Can play from 2016 and Kerem Demirbay plays from 2017 (Karli 2018). These examples provide evidence of the contribution of the immigrant players to German national teams' success in international competitions.

\section{IMMIGRANT PLAYERS AND GERMAN IDENTITY DEBATE: THE CASE OF MESUT ÖZİL}

In the historical process, the German national football team has been a place of German football players with Turkish roots. Many of them have not been active face in newspapers and magazines with their political comments and having the target of German media concerning the German identity perspective. An exception here is Mesut Özil whose decision to start playing in the German national football team has created critical discussions since 2009. In the early phase of his football career, he found himself in the national identity discussions between Turkey and Germany those created debates in the media of both countries. As a German with Turkish roots born in Gelsenkirchen in 1988, Mesut Özil had a life cycle that brought him to be a football player. Since 1995, starting from 'DJK Westfalia 04 Gelsenkirchenand' later 'DJK Teutonia Schalke-Nord' and 'DJK Falke Gelsenkirchen', Özil continued his football career in 2000 at 'Rot-Weiss Essen' and with the influence of his father he continued his career at 'Schalke $04{ }^{\prime}{ }^{3}$ Later, he transferred to 'Werder Bremen'. This followed his first international football team experience out of Germany as transferring to 'Real Madrid' in 2010. Since 2013, he has been playing at 'Arsenal FC'. Concerning playing at the national teams, he started his national football team career with the German young national football team. His notable success was during UEFA European Under-21 Championship in Sweden in 2009. During the final match, Germany vs. England, he scored a goal against England and Germany won 4-0 against England. After the match, he was declared as the "star of the show" in the German media (Chase 2009).

\footnotetext{
${ }^{3}$ According to Soner Yalçın (2018), when Özil was playing at Schalke 04, he wanted to play in a Turkish team. He applied to both Galatasaray and Beşiktaş in 2005. However, both teams did not offer any contract for him with the comments of him as "This kid is skinny as a worm; do not have a football player type". So, he went back to Germany without trying his chance with Fenerbahçe.
} 
Concerning the decision of German football players with the Turkish root to play either German or Turkish national football teams, the famous politicized competition was over Mesut Özil. In 2009, Özil declared his decision on playing in the German national football team. Özil explained his decision by expressing that "I was born here, grew up here, and my football is German" (Yinanç 2018). While this was welcomed with great support in the German media, it had critics in the Turkish media that lead critics to the coach of the Turkish national football team, Fatih Terim. Thus, the critics in the Turkish media were that Terim was not interesting in Özil's play in the Turkish National Football Team (Toroğlu 2010).

However, against this criticism Terim's response was related to questioning these players' national consciousness. Thus, he reflected his idea of these players being regarded as traitors by the Turkish public. Terim mentioned:

I have 30-40 files that say 'No' to the invitation letter we sent. Some players are not even 17 years old. We take measures to protect them as they should not be disturbed, with the questions of 'Why they did not choose the national team.' We do not allow an 18-year-old boy to negotiate with the jersey of the national team. It is the jersey of the national team. We have to keep the quality and the honor of it (Haber 7 2010).

As it is seen from Terim's arguments, this threatening perspective as being a traitor because of not showing up at the Turkish national football team is visible. Moreover, concerning the immigrant players' being on the national team of Germany, it was also regarded as important for the integration of them in the overall public sphere of Germany. Thus, after the decision to play in the German national football team, Özil mentioned that "this decision does not mean that I deny my Turkish origin. I feel that I have duties in the integration process of immigrants" (Danışman 2009). In this sense, Özil's argument shows that he also agrees that contributing to the success of the German national football team is a positive approach to the integration of immigrants that have been in cohesion with German media at that time based on immigrants' contributing to society with their success.

In the political sphere, Özil's decision was embraced with great support in Germany. The notable arguments came from Maria Böhmer, Minister of State for Integration in the Federal Chancellery, and regarded this as a good sign of the integration and immigrant's contribution to Germany. Also, the Green Party declared Özil as an important example to everybody in Germany. Having a Turkish root Gül Keskinler, who is responsible for integration within the German Football Federation (DFB), argued:

we have young people here (in Germany), schooling, unemployed, but some children cannot improve themselves because of their families, 
children who cannot come to certain (work) places. For them, Serdar, Mesut, these favorite names have great importance. And it's a good example for them to be like Mesut (Danışman 2009).

As the first world cup experience, Özil played in the German national football team during the 2010 FIFA World Cup in South Africa. He scored the first goal of the national team against Ghana. He contributed to Germany's coming in third in the World Cup. As a result of the impressive performance during the FIFA World Cup, Özil started to have more visibility in the mainstream German media with his life and success stories. Wigbert Löer (2010) in his column in Stern portrays Özil as a German-Turk. He argues that "he feels like a Turk and speaks Turkish at home. His fathers had given him the choice, and so Özil said one day the national coach, 'I want to wear the German jersey.' He never had to think about that, he says" (Löer 2010). In this regard, the article bases on Özil's contribution to the national team even as 'they speak Turkish at home' and not belonging to a traditional German family. This shows a positive approach to Özil because of his success story in the national team.

Moreover, during the Germany vs. Turkey football match of EURO 2012 qualifying, Germany won 3-0 against Turkey and Özil scored a goal at the $79^{\text {th }}$ minutes of the match against Turkey. However, he did not celebrate his success after the goal. Özil at the German national team was booed by the fans of the Turkish national team by regarding Özil as being Turkish but serving to the German national team. At the same time, Özil was criticized by the German football fans of the national team as he did not sing the German National Anthem (Oran and Çopur 2014, 133-160). In this sense, he has been on the point of critics on both sides. However, while this was true to the matches between Turkey and Germany, for Germany's other matches, Özil was followed by the Turkish public and supported as the source of pride because of his Turkish roots. Furthermore, Özil successfully contributed to the German national football team during the 2014 FIFA World Cup in Brazil.

During the tournament, Özil scored one goal and 3 assists. Thus, Özil became an important game builder and contributed to Germany's becoming the world champion as a result of the tournament. During the tournament, Özil was on the screen of German media. Rather than emphasizing his Turkish origin, the discourses in the mainstream media have been on Özil as "Der Deutsche Nationalspieler Mesut Özil (the German national player Mesut Özil)" (RPOnline 2014). Because of his success stories during the World Cup tournament, Özil's motivational arguments brought into fore that shows a solidarity circle around the national team. Thus, Özil argued that "we can beat any team if we do our best. We can become a legend by becoming the first European team in South America to win a World Cup" (RPOnline 2014). Furthermore, after the World Cup championship of Germany, mainstream media of Germany continued to give news from Özil. 
Thus, Spiegel (2014) brought Özil's interview in the Daily Telegraph to the agenda by regarding Özil as the world champion and the most expensive German player in the world as he was playing in FC Arsenal. It shows that the success of Özil himself and his contribution to the German national football team affected his acceptance of the national identity. He became the source of pride for Germany's football history because he caused the emergence of significant discussions around the world.

The next international competition for Germany's national football team is the Euro 2016 Cup organized in France. This time the Euro 2016 Cup coincided with the Muslim holy month Ramadan. Before the tournament, a specific discussion of the German media related to Mesut Özil was the impossibility of fasting during Ramadan, which is at the time of the Euro 2016 Cup. As an example, Tagesspiegel (2016) with the headline "Mesut Özil: 'Impossible to fast during the European Championship'" on 1 June 2016, shared the discussion of how Özil can be fasting during Ramadan by showing his picture in Mekka, where Özil went there in the same year for the pilgrimage. In this regard, by presenting Özil as an observant Muslim, the newspaper shared the thoughts on that professional players can fast out of Ramadan instead of the days during the religious month Ramadan. So, the expectation was shared with the public of Özil's not fasting during Ramadan by thinking about the success of the national team.

The German national football team could not achieve the desired goal to win the European championship in 2016. In the semi-final, Germany lost the match against France and took a leave from the tournament. Moreover, in the FIFA Confederation Cup organized in Russia, Germany won the 2017 FIFA Confederation Cup. It was Germany's first confederation cup. The German national football team participated in the tournament with the absence of important players including Mesut Özil. However, they succeeded to win the cup.

\section{DISAPPOINTMENT AT THE 2018 WORLD CUP AND ÖZIL AS AN IMMIGRANT PLAYER}

As it was mentioned, Özil's visit to Mekka in 2016 for the pilgrimage found a place in the mainstream media in Germany. This created specific critics as well as supportive arguments in social media discussions. At that time, Germany was struggling with the increasing numbers of refugees coming from Syria that created tension in German society as Germany is leading toward the Islamization process ${ }^{4}$.

\footnotetext{
${ }^{4}$ In the post-2011 process, after the protests and transformations started in the Middle East, Germany faced with a refugee flow as many other countries in Europe. The public discussion about this process was based on criticizing the Prime Minister Angela Merkel's policies to accept refugees and regarded the Muslim refugees as the terrorists of tomorrow. During this period, notable publications in relation to the media's interest published such as Thilo Sarrazin's "Deutschland schafft sich ab (Germany Is Doing Away With Itself)" (2010) and "Feindliche Übernahme: Wie
} 
So, Özil's pictures in Mekka during the pilgrimage were circulated in the media created particular discussions as exclusionary and anti-Islam discourses that show the rise of anti-Muslim racism in Germany. An important example in this regard came from the anti-immigrant Alternative for Germany (AFD)'s Saxony branch. Thus, Saxony district's executive of AFD, Andrea Kersten, regarded Özil's pilgrimage as an "antipatriotic signal" (Hendrich 2016). According to Malte Lehming (2016), "Mesut Özil's pilgrimage to Mecca fascinates and irritates so many Germans." For Lehming, this irritation is related to Germany's cultural situation of having a distance from religion. Thus, society constitutes a secular society, and religious practices are not widely seen. Also, they do not see the important politicians and famous people to be in a religious ceremony that the strong religious emphasis of Özil with his pilgrimage to Mekka is the main reason for this fear and irritation.

Moreover, another wide criticism of Özil came after Özil met with Turkish President Recep Tayyip Erdoğan in London in May 2018. At this meeting, German national players Mesut Özil and İlkay Gündoğan met with President Erdoğan. During that time Turkey was under the presidential election process that is regarded in the German public opinion as to the support of them to Erdoğan who was also a candidate in the elections. Even not only Özil but also Gündoğan met with Erdoğan, the specific criticism turned to Özil because of his position as a publicly known religious figure that leads to being classified as a pro-Erdoğan conservative Turk. The President of DFB, Reinhard Grindel, criticized this meeting and argued on Twitter that "of course, the DFB respects the special situation of our players with a migration background, but football and the DFB stand for values that are not sufficiently respected by Mr. Erdoğan" (Focus 2018).

Grindel's position of criticizing both players and talking about the values of DFB cannot be thought out of the political tension between Turkey and Germany during that time. Thus, the majority of Germany's social and political spheres regarded the post2013 Gezi Park Protest time in Turkey as an authoritarian nation that gradually diminished the social and political rights of the citizens. In this regard, the public perspective on Turkish politics was based on supporting the opposition and being against Erdoğan's political way of creating distance between Turkey and Europe. Therefore, a German national football player was expected to follow this general understanding and for an immigrant player, it is a signal of the integration into German society. Thus, Grindel also argued that this behavior of these players shows "the integration work of the DFB certainly did not help our two players with this action" (Focus 2018). This shows that rather than a place of football, the national football team is regarded in Germany as a place of reflection of social and political values that were expected to be respected by the players within.

der Islam den Fortschritt behindert und die Gesellschaft bedroht (Hostile takeover - how Islam impairs progress and threatens society)" (2018). 
Concerning this, another notable criticism came to both players about their approaching Erdoğan as their president. Thus, after the meeting of Özil and Güldoğan with President Erdoğan, a signed jersey was shared from the official Twitter account of Erdoğan's party AKP stating that "With respect for my president" (Spiegel 2018). This was criticized by Bundestag member Cem Özdemir, who has also a Turkish origin, that "the President of a German national player is called Frank-Walter Steinmeier, Chancellor Angela Merkel and Parliament is called the German Bundestag (...) It sits in Berlin, not in Ankara" (Spiegel 2018).

Özdemir's arguments are important in the context of regarding players on the national football team as accepting and respecting the identity perspective of the national team's belonging country. This shows how important function has the national football team for the formation of the identity. Moreover, this requires also to have a patriotic stance. Since Özil has met with Erdoğan more than five times from 2011, 2012, 2016, 2017, 2018, but the only 2018 meeting irritated the society and the politicians (Krause et al. 2018). In this sense, it depends on the level of the relationship of both countries as 2018 has been in a tense year between Turkey and Germany because Turkey imprisoned some German journalists (e.g. Deniz Yücel) that were followed by society. After all, the German media brought these tensions to the public agenda.

According to Mesut Özil, "certain German newspaper" used the photo for right propaganda, "to advance their political interests" (Tagesschau 2018). Özil also mentions that after these negative advertisements of media, sponsorship agreements of an official sponsor brand was canceled. For Özil, "It was no longer good for them to be seen with me, they called this situation 'crisis management'" (Tagesschau 2018). Besides, the manager of the coach of German national football team Joachim Löw, Harun Aslan mentioned that Özil went to meet President Erdoğan with his own will. For him, it was an invitation and could be refused if Özil wanted not to meet Erdoğan (NTV 2018). After 24 June 2018, presidential election in Turkey, Erdoğan became the President of Turkey and in the mainstream German media, Özil's meeting with Erdoğan before this election was regarded as instrumentalized to increase Erdoğan's popularity (Welt 2019).

Moreover, following these critiques, Germany's early farewell to the World Cup in 2018 pointed to Özil with the arguments about his poor performance. These excessive critics over Özil are being regarded as Özil to be made Germany's "scapegoat" (Watson 2018). According to Özil's father Mustafa Özil "It's always said that if we win, we win together, but if we lose, we lose because of Özil. He's booed and put up as a scapegoat - I completely understand that he is offended" (Watson 2018). As a result of these all developments, on 23 July 2018, Özil declared in his Twitter account his resignation from Germany's national football team with his long explanations. The critics after his meeting with President Erdoğan seem the most important reason for this decision. 
In his statement, Özil mentions that he found the treatment of DFB unfair after he met with Erdoğan and it affected him to not play anymore in the German national team's jersey. Thus, by making direct reference to the President of DFB, Reinhard Grindel, Özil argues:

People with racially discriminating backgrounds should not be allowed to work in the largest football federation in the world that has players from dual-heritage families. Attitudes like theirs simply do not reflect the players they supposedly represent. In the eyes of Grindel and his supporters, I am German when we win, but I am an immigrant when we lose (...) It is with a heavy heart and after much consideration that because of recent events I will no longer be playing for Germany at the international level whilst I have this feeling of racism and disrespect. I used to wear a German shirt with such pride and excitement, but now I don't. I feel unwanted and think that what I have achieved since my international debut in 2009 has been forgotten (...) I will no longer stand for being a scapegoat for his incompetence and inability to do his job properly (...) I am disappointed, but not surprised by [Grindel's] actions (...) But when high-ranking DFB officials disrespect my Turkish roots and selfishly turn me into political propaganda, then enough is enough (Bryant 2018).

Moreover, not only about the official institutions in Germany, but he also reflected some people's racially discriminatory perspective in German society. Özil revealed in his explanations that he received many comments, e-mails, and messages, including hate speech against him and his family. Thus, Özil gave an example of a German fan told him after the match against Sweden during the World Cup in 2018 that "Özil, fuck off you Turkish shit, piss off you Turkish pig" (Bryant 2018). In Özil's perspective, this represents the old Germany that he is not finding a place for himself. So, this treatment shows the effect of the success in the German national football team for inclusion in the national identity perspective. After Özil's these explanations, some responses came from sports arenas and institutions related to sport in Germany. Thus, President of Bayern Munich Uli Hoeness argued:

Özil has been playing shit for years. He won his last tackle before the 2014 World Cup. All he is doing in the field is playing cross passes. Now he hides himself and his crap performance behind this photo... Whenever we played against Arsenal, we played over him, because we knew he was the weak point (Bryant 2018).

Moreover, DFB denied racism claims of Özil against them and mentioned that Özil made great contributions to the 2014 World Cup. But his photos with Erdoğan raised questions from many people, and they had to make comments about it (Bryant 
2018). Overall, Özil's arguments with his resignation from the German national football team and the counter-arguments against his claims show that the success of Özil on the national team was the major determinant of his being regarded as a German by the mainstream media of Germany.

\section{CONCLUSION}

As the case study of this paper reveals, Mesut Özil started to play at the German national football team in 2010 and made notable contributions to Germany's winning the world cup in 2014. This success of Özil brought him to the scene as one of the most popular players and was regarded at that time in the mainstream German media as the most valuable German football player in the world. However, because of Germany's unsuccessful time during the Euro 2016 Cup and the 2018 World Cup, major critics came to the immigrant players as the scapegoats of the team. In this regard, Özil started to be visible in the media with the pictures of his pilgrimage to Mekka in 2016 and his meeting with Turkey's President Recep Tayyip Erdoğan, and his religious personality. While his German identity was popularly mentioned during the successful times of the German national football team, the discourses in the media and national institutions as well as in the public at the unsuccessful times referred to Özil's Turkish background. This resulted in Özil's resignation from the German national football team with his words, "I am a German when we win, but an immigrant when we lose" (Bryant 2018). Overall, these all research and analyses reveal that the success of a player with an immigrant background in the national football team is an important determinant of inclusion in the German national identity. 


\section{REFERENCES}

1. Bryant, Tom. 2018. "Mesut Özil Walks Away from Germany Team Citing 'Racism and Disrespect'". The Guardian, July 23. Accessed September 12, 2020.

https://www.theguardian.com/football/2018/jul/22/mesut-ozil-retires-germannational-team-discrimination.

2. Chase, Jefferson. 2009. "Under 21s Provide a Mixed Picture of Germany's Footballing Future". DW, June 26. AccessedAugust 15, 2020. https://www.dw.com/en/under-21sprovide-a-mixed-picture-of-germanys-footballing-future/a-4421552.

3. Danışman, Jülide. 2009. "Mesut Chooses German National Team”. DW, February 6. AccessedAugust 15, 2020. https://www.dw.com/tr/mesut-alman-millitak\%C4\%B1m\%C4\%B1n\%C4\%B1-se\%C3\%A7ti/a-4005948.

4. Focus. 2018. "Türkei-Präsident Erdogan posiert mit DFB-Stars Özil und Gündogan". AccessedAugust 12, 2020.https://www.focus.de/sport/fussball/treffen-in-londontuerkei-praesident-erdogan-posiert-mit-dfb-stars-oezil-undguendogan id_8925486.html.

5. Goksoyr, Matti. 2010. "Nationalism." In Routledge Companion to Sports History, edited by S. W. Pope andJohn Nauright, 268-294. London, New York: Routledge.

6. Haber 7. 2010. "What did Mesut Özil's father offer Terim?" AccessedAugust 12, 2020. http://spor.haber7.com/spor/haber/348936-mesut-ozilin-babasi-terime-ne-teklifetmis.

7. Hendrich, Cornelia. 2016. "AfD kritisiert Özils Pilgerreise nach Mekka." Welt, May 30. AccessedAugust 13, 2020. https://www.welt.de/politik/deutschland/article155809152/AfD-kritisiert-OezilsPilgerreise-nach-Mekka.html.

8. Heywood, Andrew. 1994. Political Ideas and Concepts: An Introduction.London: Macmillan.

9. Hyde, Marina. 2006. "League of Nations Allows Germany to Fly Flag with Pride." The Guardian, July 10. Accessed June 17, 2020.

https://www.theguardian.com/football/2006/jul/10/worldcup2006.sport5.

10. Karli, Fuat. 2018. "7 Soccer Players of Turkish Origin that Dressed in the German National Team." 90 Min, July 26. AccessedAugust 12, 2020. https://www.90min.com/tr/posts/6127421-turk-kokenli-olup-alman-milli-takiminda-forma-giymis-7-futbolcu.

11. Kleindienst-Cachay, Christa. (2011). "'Balancing Between the Cultures...' Sports and Physical Activities of Muslim Girls and Women in Germany." In Muslim Women and Sport, edited by Tansin Ben, Gertrud Pfister and Haifa Jawad, 92-108. London, New York: Routledge.

12. Krause, Thomas.,Finn Rütten., andFelix Haas. 2018. "Mesut Özil und seine vielen Treffen mit Erdogan." Spiegel, July 18. Accessed September 21, 2020. 
https://www.stern.de/sport/fussball/wm-2018/mesut-oezil-und-seine-vielen-treffenmit-erdogan-8163030.html.

13. Lehming, Malte. 2016. "Mesut Özil und die ganz große Ökumene." Tagesspiegel, May 25. Accessed September 17, 2020.

https://www.tagesspiegel.de/politik/pilgerfahrt-nach-mekka-mesut-oezil-und-dieganz-grosse-oekumene/13637808.html.

14. Löer, Wigbert. 2010. "Eine deutsche Fußballerkarriere." Stern, June 24.

AccessedAugust 14, 2020. https://www.stern.de/sport/fussball/wm-2010/wm-2010-mesut-oezil-eine-deutsche-fussballerkarriere-3278610.html.

15. Milewski, Nadja. 2007. "First Child of Immigrant Workers and their Descendants in West Germany: Interrelations of Events, Disruption, or Adaptation?" Demographic Research 17: 859-96.

16. NTV. 2018. "Özil hätte Erdogan-Treffen absagen können". Accessed September 20, 2020. https://www.n-tv.de/sport/fussball/Ozil-haette-Erdogan-Treffen-absagenkoennen-article20548999.html.

17. Oran, Baskın., and BurakÇopur. 2014. Identity, Diversity and Cohesion in Globalizing Nation-state. In Vielfalt und Zusammenhalt: Verhandlungen des 36. Kongresses der Deutschen Gesellsachaft für Soziologie in Bochum und Dortmund 2012, 133-160. New York, London: Campus Verlag.

18. RPOnline. 2014. "Özil: 'Wir können zu Legenden werden'." Accessed August 15, 2020. https://rp-online.de/sport/fussball/wm/dfb/wm-2014-mesut-oezil-wirkoennen-zu-legenden-werden aid-20321099.

19. Spiegel. 2014. "Ich bin einer der besten Zehner der Welt". Accessed August 16, 2020. https://www.spiegel.de/sport/fussball/mesut-oezil-nationalspieler-kontert-kritik-anwm-leistungen-a-988988.html.

20. Spiegel. 2018. "Özil und Gündogan posieren mit Erdogan." Accessed September 19, 2020. https://www.spiegel.de/sport/fussball/mesut-oezil-und-ilkay-guendogantreffen-recep-tayyip-erdogan-a-1207631.html.

21. Tagesschau. 2018. "Özil verteidigt Foto und geht Kritiker an." Accessed September 18, 2020. https://www.tagesschau.de/inland/oezil-erdogan-101.html.

22. Tagesspiegel. 2016. "Mesut Özil: 'Unmöglich, während der EM zu fasten'." AccessedAugust 17, 2020. https://www.tagesspiegel.de/sport/glaeubigernationalspieler-vor-dem-ramadan-mesut-oezil-unmoeglich-waehrend-der-em-zufasten/13671582.html.

23. Toroğlu, Erman. 2010. "Terim Wanted, I Met Him, But He Chose Germany." Hürriyet, June 15. Accessed July22, 2020.. http://www.hurriyet.com.tr/terim-istedi-bengorustum-ama-o-almanya-yi-secti-15024020.

24. Watson, Jack. 2018. "World Cup 2018: Mesut Özil Urged by his Father to Retire After being Made Germany's 'Scapegoat'." Independent, July 9. Accessed September 23, 2020.https://www.independent.co.uk/sport/football/world-cup/world-cup-2018- 
mesut-ozil-germany-retire-international-football-father-arsenal-newsa8438471.html.

25. Welt. 2019. "Özil soll Erdogan um einen Gefallen gebeten haben." Accessed September 11, 2020. https://www.welt.de/sport/fussball/article190391115/MesutOezil-Bei-Treffen-mit-Erdogan-bat-er-ihn-wohl-um-einen-Gefallen.html. 26. Yalçın, Soner. 2018. "Mesut Özil and the Monkey Cage." Odatv, July 24. Accessed September 2, 2020. https://odatv.com/mesut-ozil-ve-maymun-kafesi24071848.html.

27. Yinanç, Barçın. 2018. "Özil 'Shined a Mirror in the Face of the German Nation'." Hürriyet Daily News, July 30. Accessed September 14, 2020. http://www.hurriyetdailynews.com/ozil-shined-a-mirror-in-the-face-of-the-germannation-135172. 